\title{
Izolacja i komunikacja. Rodzaje izolacji i towarzyszące im deficyty komunikacyjne
}

\section{JACEK WASILEWSKI}

ORCID: 0000-0003-I926-9950

(Uniwersytet Warszawski)

Celem artykułu jest przeanalizowanie rodzajów izolacji i charakteryzujących je deficytów komunikacyjnych. Izolacja jako relacja człowieka ze światem może być wartościowana pozytywnie lub negatywnie. W związku z tym można postawić tezę, że wartościowanie izolacji zależy od możliwości kontroli wymiany ze światem, czyli poczucia wpływu na rzeczywistość. U podstaw tego ujęcia leży założenie, że człowiek jest w stanie kontrolować sytuację nie tylko przez własne działanie w świecie, ale także przez interpretację wydarzeń - sposób ich rozumienia, określenia celowości lub przyczyn. Izolacja powoduje stres. Próby jego opanowania wymagają wysiłku, który może być podejmowany w ograniczonym zakresie. Jeśli angażujemy się w jeden akt kontroli, zdolności do kontrolowania siebie w inny sposób zmniejszają się $e^{I}$ Próba opanowania stresu izolacyjnego będzie wpływać na modele komunikacji i jej treść, co ma konsekwencje w tworzeniu narracji o sobie i o świecie.

Kluczowe pojęcia w prezentowanym podejściu wynikają z definicji sytuacji, którą stwarza izolacja: oznacza ona oddzielenie się od kogoś lub odseparowanie kogoś - jednostki od grupy lub grupy od jednostek. To oddzielenie czy odizolowanie może być dobrowolne lub przymusowe. Metodę pracy, na której będzie opierać się analiza konsekwencji komunikacyjnych dla tak wyszczególnionych przypadków, nazywa się w semiotycznej praktyce analitycznej notness ${ }^{2}$. Odwołuje się ona do strukturalistycznego modelu mitu, zaproponowanego przez Claude'a Lévi-Straussa. Mit identyfikował i wskazywał najważniejsze w kulturze opozycje,

1 R. Baumeister, Zwierzę kulturowe, tłum. D. Stefańska-Szewczuk, Warszawa 2011, s. 327-328.

2 V.Valentine, The 'Notness' Principle - a Semiotic Model of Meanings, dokument prezentowany na Market Research Society Training Seminar, Londyn, luty 2001. 
które wplatał w ludzkie doświadczenia. Koncepcja notness rozwija tę myśl w taki sposób, że człowiek ma rozpoznawać wszelkie zjawiska wokól siebie przez ich przeciwieństwa, negacja jest więc podstawowym mechanizmem zyskiwania i nadawania znaczenia. Dobro różni się od zła, ciemność od światłości, matka to nie ojciec itd. Koncepcja notness oznacza, że kluczem do zidentyfikowania i rozszyfrowania kulturowych sensów pozostaje zdefiniowanie opozycji, w które dane zjawisko jest uwikłane 3 .

\section{Odizolowanie}

Porucznik szwoleżerów Karol Piątkowski udał się dobrowolnie z Napoleonem na Wyspę Świętej Heleny, dokąd z Europy płynęło się dwa miesiące. Po roku Londyn zdecydował zmniejszyć liczbę osobistej świty pokonanego wroga, więc polski oficer musiał to miejsce opuścić w I8I6 roku. Ta wulkaniczna wyspa leży na Oceanie Atlantyckim blisko dwa tysiące kilometrów od wybrzeży Afryki. Okazało się, że Elba była położona zbyt blisko Europy i charyzma Napoleona wpływała na umysły wielu ludzi, rozpalając ich ambicje. Dlatego trzeba go było lepiej odizolować. W dodatku na wyspie, która ma około sto dwadzieścia dwa kilometry kwadratowe, odgradzało go od świata pięciuset żołnierzy. Izolację pogłębiało ograniczenie korespondencji, swobody poruszania się czy ewentualnych wizyt, a także z czasem minimalizacja zasobów drewna i żywności ${ }^{4}$. W końcu również informacje przedostawały się z trudem, Napoleonowi dostarczano regularnie „The Times”, w którym W I8I8 roku zamieszczono depeszę o tym, że wiadomość o rzekomej ucieczce „boga wojny" z wyspy londyńczycy przyjęli z ukontentowaniem.

Ta historia pokazuje kilka istotnych kwestii związanych z izolacją i komunikacją. Słowo „izolacja” ma swój źródłosłów w łacinie - insulatus oznaczało coś uczynionego na kształt wyspy ${ }^{5}$ odrębnej, oddzielnej, niepołączonej z jakąkolwiek resztą. W XVIII stuleciu, gdy Napoleon się narodził, używano tego określenia również w kontekście blokowania przepływu ciepła czy elektryczności, a pół wieku po śmierci cesarza Francuzów zaczęto mówić o materiale izolacyjnym. W tej historii cesarskiej świty na Wyspie Świętej Heleny mamy do czynienia z dwoma

3 Por. G. Kapuściński, Tańce wokót krzyża. Analiza semiostrukturalna zachorwań podczas demonstracji pod Patacem Prezydenckim, „Miscellanea Anthropologica et Sociologica” 2012, nr 13, s. 126.

4 W. Scott, The Life Of Napoleon Buonaparte, Emperor Of The French, J\&B Williams, 1832 (https:// books.google.pl/books?id=SqmXIp6IRpoC\&hl=pl\&source=gbs_navlinks_s, stan z 10 października 2021 r.).

5 Izolacja (franc. isole, wł. isolato, 1ac. insulatus) - uczyniony na kształt wyspy; za: Concise Oxford English Dictionary, red. A. Stevenson, M. Waite, New York 2011. 
rodzajami izolacji $-\mathrm{z}$ izolowaniem przymusowym Napoleona lub z izolowaniem się dobrowolnym w przypadku szwoleżera z Polski. Mamy także do czynienia z wygnaniem kogoś, odłączeniem od społeczeństwa, odseparowaniem wodami oceanu i strażą kilkuset żołnierzy. Archetypem może być tu Filoktet, którego Odys ze względu na ropiejącą ranę, jęki i smród zgnilizny kazał zostawić na wyspie Lemnos ${ }^{6}$. Ponadto obserwujemy odłączenie się społeczności od świata, kiedy to bez odbycia kwarantanny nie wolno wejść do danego miejsca.

Można też izolować się od innych. W wersji elitarnej jest to przypadek opisany w Dekameronie Boccaccia, gdy elita odgradza się od łatwo zarażającego się plebsu. $\mathrm{Z}$ czasów takich zaraz pochodzi dodane do modlitwy Zdrowaś Mario wezwanie do Maryi o wstawiennictwo w trudnej godzinie, kiedy śmierć czai się w powietrzu: „Święta Maryjo, Matko Boża, módl się za nami grzesznymi teraz i w godzinę śmierci naszej", zatwierdzona w końcu przez papieża Piusa V w XVI wieku. W wersji bardziej demokratycznej opisuje to polski podróżnik Franciszek Bohusz, który w swoim Diariuszu podróżnika notuje sposób zabezpieczeń przeciw epidemii w Livorno. Mieszkańcy nie wpuszczali drogą morską nikogo podejrzanego o możliwość zarażenia chorobą lub przewożenie potencjalnie niebezpiecznych - mogących być źródłem zakażenia - towarów ze wschodu. Każda jednostka, zanim wpłynęła do portu, była sprawdzana przez komisję zdrowia, musiała legitymować się odpowiednimi dokumentami i pod karą śmierci poświadczyć brak zakażenia chorobami epidemicznymi. Towary zaś zamykano w lazarecie wraz z załogą, a jeśliby u któregokolwiek z jej członków wystąpiły objawy choroby, wówczas je palono. W trakcie epidemii dzielono załogi na kompanie, a po czterdziestu dniach kwarantanny przychodził lekarz i zwalniał z niej tych, którzy zachowali zdrowie?

W przypadku Napoleona pojawiły się fałszywe pogłoski z powodu ograniczenia informacji. Czasem występuje odmienne zjawisko - właśnie z powodu wolności informacji na pewnym terenie przypisuje się tym obszarom fałszywe atrybucje. Przykładem może być okres pandemii grypy z lat I9ı-I9I9.

\section{》Średnia śmiertelność szacowana jest na ok. 2-Io\%, choć w pewnych izolowanych środowiskach sięgała ona nawet $20 \%$, jak w przypadku armii amerykańskiej. W ciągu pierwszych 25 tygodni od wybuchu}

6 Historie o zostawieniu na wyspie wciąż zdarzają się w rzeczywistości - np. portal związany z radiem RMF donosił, że rodzice pozostawili trzynastoletnią córkę na bezludnej wyspie, aby dać jej nauczkę. Dziewczyna miała pyskować i nie słuchać się ich. Na domiar złego nastolatka porzuciła szkołę i całymi dniami przesiadywała w pokoju. W czasie izolacji miała ze sobą ciastka i wodę. Po dwóch dniach została uratowana przez rybaka, który wezwał policję, a ta kazała rodzicom zabrać krnąbrną córkę. Zob. https://www.rmf24.pl/fakty/swiat/news-rodzice-zostawili-13-latke-na-bezludnej-wyspie-chcieli-dac-j,nId,5358549\#crp_state=1 (stan z 14 sierpnia 2021 r.).

7 F.K. Bohusz, Dziennik podróży, wstęp i oprac. F. Wolański, Kraków-Wrocław 2014. 
pandemii, grypa mogła zabić nawet 25 milionów ludzi. Dla porównania - wirus HIV, odpowiedzialny za pandemię AIDS, pochłonął taką samą liczbę istnień w ciągu pierwszych 25 lat swojego istnienia. Eączny bilans ofiar „hiszpanki” szacuje się na 50-Ioo milionów. [...] O pandemii z lat I918-I9I9 mówi się powszechnie „hiszpanka” czy „hiszpańska grypa”, choć tak naprawdę kraj z Półwyspu Iberyjskiego nie odegrał żadnej znaczącej roli w rozprzestrzenianiu się grypy. Przyczyną takiego stanu rzeczy jest fakt, iż Hiszpania była jednym z nielicznych krajów, który zachował neutralność w trakcie I Wojny Światowej. Co za tym idzie, na jej obszarze nie było cenzury wojennej, więc prasa mogła bez ograniczeń rozpisywać się na temat niosącej śmierć choroby. Informacje te docierały do krajów, w których obowiązywała cenzura, a temat grypy nie był poruszany, by nie obniżać dodatkowo morale. Logicznym więc było, że skoro doniesienia płynęły z Hiszpanii, to właśnie ten kraj był pierwotnym ogniskiem zakażenia wirusem ${ }^{8}$.

\section{WOLA I PRZYMUS}

Mamy zatem dwie zasadnicze osie - oś woli, która wyznacza stosunek do izolacji, oraz oś kierunku izolacji, która obrazuje relacje między jednostką a grupą. Jeśli moją wolą jest się izolować, jestem niczym Szymon Słupnik, wybierający swą napowietrzną pustelnię i koncentrujący się na sprawach poza opuszczoną przeze mnie społecznością. $Z$ jednej strony mamy wygnańców - tych, którzy nie z własnej woli zostali zmuszeni do opuszczenia swoich miejsc, odcięcia się od korzeni. Może to być Odys, którego bóg morza odpędził od brzegów Itaki. Po drugiej stronie mamy twierdzę, która nie dopuszcza do siebie nikogo z zewnątrz - jak włoskie Livorno czy więzienie, jakim były dla Napoleona jego ostatnie wyspy: Elba i św. Helena, a jaką nie była Korsyka, na której się urodził. To Europa na tych wyspach uczyniła mu więzienie i odizolowała go od siebie jako zagrożenie dla ładu i życia, podobnie jak Ludwik XIV odizolował w więzieniu legendarnego Człowieka w Żelaznej Masce.

8 T. Zahorski, I.Zendran, Ztoty wiek grypy. Krótka historia pandemii, w: Acta Uroboroi. W kręu epidemii, red. M. Dąsal, Wrocław 2018, https://depot.ceon.pl/bitstream/handle/123456789/15946/Acta\%20 Uroboroi-\%20W\%20Kr\%C4\%99gu\%20Epidemii\%20\%28M.D\%C4\%85sal\%20red.\%29. pdf?sequence=1\&isAllowed=y ( $\operatorname{stan}$ z 10 października 2021 r.). 


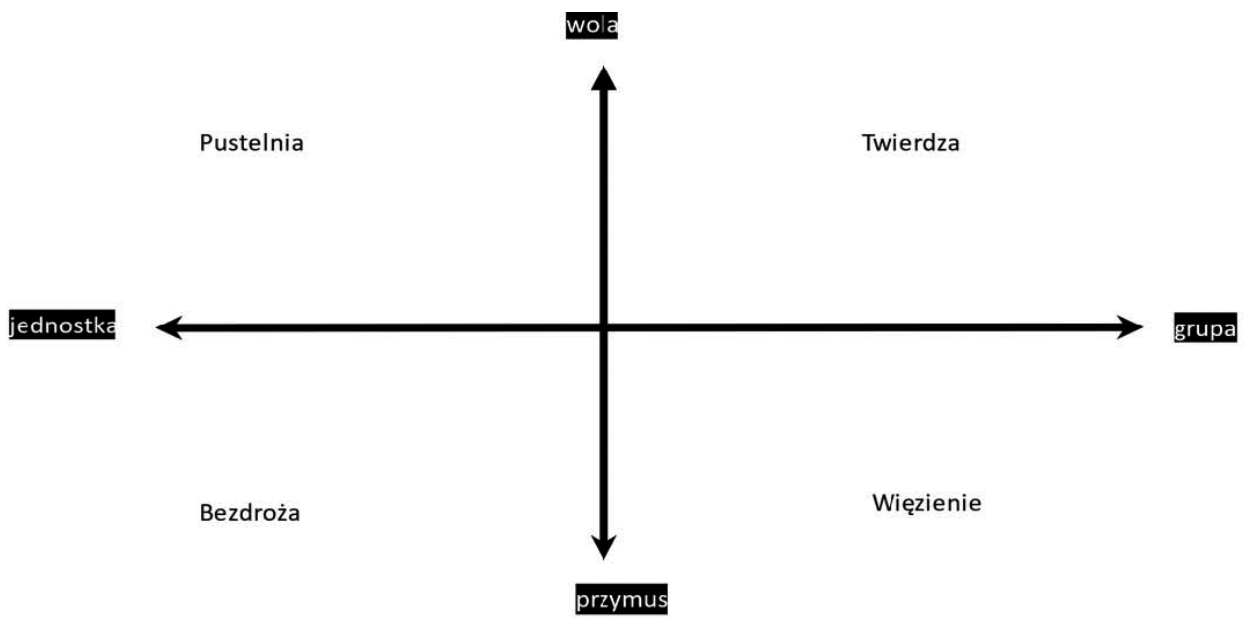

W każdej z tych kwart występuje inny rodzaj izolacji i deficytów komunikacyjnych.

I. Dla miejsc takich jak twierdza charakterystyczne jest zjawisko echo chamber czy bańki informacyjnej ${ }^{9}$, a także myślenie spiskowe.

2. Dla miejsc takich jak pustelnia charakterystyczna jest deprecjacja tego, co pochodzi od izolowanego świata.

3. Dla miejsc takich jak więzienie charakterystyczne są reglamentacja informacji i cenzura.

4. Dla bezdroży i pustkowi, które towarzyszą tułaczce, charakterystyczna jest dezintegracja, rozpad tożsamości ze względu na brak przynależności, tymczasowość i fragmentaryczność komunikacji ${ }^{10}$.

9 Zjawisko zostało zdefiniowane przez Eliego Parisera, który w książce The Filter Bubble. How the New Personalized Web Is Changing What We Read and How We Think (New York 2012) zauważa, że algorytmy podają użytkownikom bardziej jednorodne informacje, zamykając ich we własnych bańkach informacyjnych, czyli intelektualnie izolując od innych punktów widzenia. Nie zostało to potwierdzone jako powszechne zjawisko, a jeśli już, to zawężone do różnych kontekstów, zwłaszcza politycznych.

10 Pojęcie „bezdroży” bardziej wiąże się tu etymologicznie z poruszaniem się bez wyraźnego kierunku, dryfowaniem. Droga zwykle prowadzi ku jakiemuś miejscu, natomiast wygnanie jedynie zaczyna się od danego miejsca. Łączy się z tym w obecnych czasach kilka współczesnych zjawisk wyobcowania, które, jak pisze Piotr Domeracki, „oznacza równocześnie, z jednej strony, bycie pozbawionym obcowania z drugimi, nie-współ-bycie, z drugiej zaś strony poczucie bycia obcym, wyłączonym spośród swoich bądź bycie uznawanym lub/i traktowanym jak obcy, obojętny lub wrogi, mimo iż wcześniej było się uznawanym lub/i traktowanym jak ktoś znany, bliski i drogi” (idem, Rozstaje samotności. Studium filozoficzne, Kraków 2016, s. 51). Wyobcowanie może również dotyczyć osadzenia w „nie-miejscu", czyli w przestrzeni, której nie można zdefiniować ani jako tożsamościowej, ani jako relacyjnej, ani jako historycznej. Por. M. Augé, Nie-miejsca. Wprowadzenie do antropologii hipernowoczesności, tłum. R. Chymkowski, Warszawa, 2011, s. 53-71). Przykład wyobcowania tego typu możemy 
Spróbujmy je pokrótce omówić w kontekście komunikacji. Powstanie sytuacji twierdzy, w której definiujemy wroga, może się przejawiać w odkrywaniu, że jest się bojownikiem o prawdę. Taka postawa wyraża się w tym, że neguje się oficjalne kanały informacyjne i odkrywa własną prawdę, która obnaża rzeczywiste oblicze tego, co się wokół dzieje - czyli na przykład jak podmiot padał ofiarą oszustwa i jak musi stawić czoło zmasowanemu atakowi.

Przypatrzmy się badaniom z początków pandemii, gdy nasza wiedza była dość ograniczona i izolacja informacyjna sprawiała, że roztaczały się przed nami rozmaite fantasmagorie dotyczące środków obrony przed wirusem. Zadziwiające, jak wiele osób wierzyło w fake newsy o zabezpieczeniach przed koronawirusem: $32 \%$ uważało, że bardzo wysoka temperatura pomaga w leczeniu, I3\% twierdziło, że witamina $\mathrm{C}$ jest skutecznym lekiem, a Iı\% sądziło, że przed chorobą zabezpiecza spożywanie alkoholu ${ }^{\text {II }}$. Istotniejsze są jednak dane dotyczące próby wpisania koronawirusa w polityczne teatrum światowych spisków, co wnosiłoby więcej sensu do świata odbiorców niż jedna $\mathrm{z}$ wielu epidemii, która dzięki gwałtownemu rozwojowi globalnej komunikacji rozprzestrzeniła się szybko na cały świat. Otóż jedna ósma Polaków zgadzała się ze stwierdzeniem, że koronawirus został stworzony „przez Amerykanów w celu poprawienia pozycji USA w wojnie gospodarczej z Chinami” (dokładnie I6\%) czy służył „przejęciu kontroli nad gospodarką światową” (I4\%). Podobny odsetek uważał, że koronawirus został stworzony „przez Chińczyków w celu przejęcia kontroli nad gospodarką światową" (I7\%) i że był celowo rozprzestrzeniany w lokalach gastronomicznych oraz za pośrednictwem produktów żywnościowych. To polityczna narracja o tym, że silniejszy czyha na słabszego i że mamy nieszczęście być pomiędzy - zwykle mówiło się o Rosji i Niemczech, w tym przypadku na tych pozycjach stoją globalne potęgi: USA i Chiny. Narracja o twierdzy skłania nas do zamknięcia bram i do obrony. Aż co czwarty ówcześnie badany przychylał się do tezy, że koronawirus albo $\mathrm{m}$ a $\mathrm{w}$ ye 1 i m in ow a ć najsłabszych, albo został stworzony w celu pozbycia się starszych osób (I8\%). Przy tych pytaniach pojawia się więc narracja o Big Pharmie i światowym spisku: $17 \%$ twierdziło, że koncerny farmaceutyczne są odpowiedzialne za

znaleźć w filmie Terminal (2004, reż. S. Spielberg), który na wyższym poziomie jest alegorią „apatrydyzmu” rozumianego jako „bezojczyźnianość”, tj. brak przynależności i przywiązania do jakiegokolwiek miejsca, które nie jest punktem odniesienia dla autoidentyfikacji.

11 Badanie „Koronawirus w Polsce: perspektywa psychologii społecznej” (zob. http://cbu.psychologia. pl/wp-content/uploads/sites/410/2021/02/raport-koronawirus-final-.pdf, stan z 20 grudnia $2021 \mathrm{r}$.) zostało przeprowadzone w dniach 20-23 marca 2020 r., a 21 marca wykryto 111 nowych zakażeń. Do jego zakończenia w Polsce było 749 zachorowań na COVID-19 oraz 8 zgonów. Badanie było wspólfinansowane z grantu NCN 2017/26/M/HS6/00689 oraz ze środków Ministerstwa Nauki i Szkolnictwa Wyższego (DIALOG 0013/2019), wykonane we współpracy Political Cognition Lab, Instytutu Psychologii PAN i Centrum Badań nad Uprzedzeniami. 
rozprzestrzenienie się wirusa, a co dwudziesty badany uważał, że lekarze dążą do jego rozpowszechniania. Narracja ta była popularna w ostatnich filmach o Bondzie - więc aż dziwne, że tak mało osób w tamtym momencie przysposobiło ją do tego kontekstu. Ponieważ w rejonie Wuhan, gdzie lokowano źródło epidemii, produkuje się także podzespoły do sieci ${ }_{5} \mathrm{G}$, próbowano odpierać „najazd na Europę” nadajników ${ }_{5} \mathrm{G}$, paląc je i niszcząc ${ }^{\mathrm{I2}}$.

Co więcej, część osób zwróciła się przeciw pracownikom medycznym: zaczęli oni doświadczać hejtu czy też prób wygnania ze społeczności ${ }^{13}$ - początkowo dotyczyło to lekarzy pracujących w szpitalach podczas pandemii, później medyków jako agentów Big Pharmy, która chce zawładnąć ludźmi:

\Lekarze coraz częściej spotykają się z agresją. Wspominał o tym niedawno profesor Krzysztof Simon. - Jest cała gama takich wyzwisk obrzydliwych, że jesteśmy skorumpowani bandyci, ale te groźby, które były bezpośrednio, że mnie zabiją, powieszą, utopią, no i tam takie inne różne sposoby karania średniowiecznego - opowiedział profesor Krzysztof Simon, ordynator Oddziału Zakaźnego Wojewódzkiego Szpitala Specjalistycznego imienia J. Gromkowskiego we Wrocławiu. [...] Profesor Simon naraził się na agresję, ponieważ konsekwentnie zachęca pacjentów do szczepień. W trakcie pandemii problem hejtu na medyków nasilił się. Lekarze bywają piętnowani za pracę z chorymi na COVID-ı, a pod ich adresem kierowane są groźby nie tylko za promowanie szczepień, ale także choćby za zachęcanie do noszenia maseczek. - Obiecywano śmierć mnie, mojej rodzinie, za pomocą cyklonu B, porównywano do nazistów, do doktora Mengele, obiecywano karę śmierci, moi rodzice otrzymywali głuche telefony wyliczał w sierpniu Tomasz Karauda, lekarz Oddziału Chorób Płuc Uniwersyteckiego Szpitala Klinicznego imienia Norberta Barlickiego w Łodzi. Cała sprawa na groźbach się nie kończy, o czym często

12 Zob. https://www.money.p1/gospodarka/5g-zaplonely-dwa-maszty-w-lodzi-operatorzy-apeluja-do-rzadu-o-interwencje-6514905739503233a.html (stan z 1 października 2020 r.).

13 „Przedszkole: nie chcemy dziecka lekarza. Sąsiedzi: wyprowadźcie się, roznosicie zarazę. Sklep: nie obsługujemy pielęgniarek. Ich mężów też. Po brawach z balkonów przyszły: strach, hejt i dyskryminacja. [...] - Kazali mojemu mężowi iść na przymusowe postojowe w pracy. Bo ma żonę pielęgniarkę! Wszyscy uważają, że roznoszę zarazę. Co jeszcze mnie spotka, powiedz? Wracałam z dyżuru. Weszłam do małego sklepu spożywczego. I słyszę, jak ekspedientki rozmawiają: «Ta to zaraz nam tu syfa przyniesie, to pielęgniarka, nie chcę jej obsługiwać»" (https://tvn24.pl/magazyn-tvn24/zaraz-nam-tu-syfa-przyniesie-brawa-szybko-umilkly-przyszedl-hejt,266,4651, stan z 9 sierpnia 2021 r.). 
przekonują się ratownicy medyczni. O pobiciach i uszkodzeniach karetek nieraz informowaliśmy $[\ldots]^{14}$.

Dla obszaru określonego jako „bezmiejsca”, czyli bezdroża i „pustkowia”, które towarzyszą tułaczce i wygnaniu (por. przypis Io), charakterystyczna jest dezintegracja więzi z otoczeniem. Stają się one tymczasowe, a komunikacja jest ograniczona - jakby wygnańcy stawali przed zamkniętymi drzwiami społeczności, do której należeli. Element komunikacyjnego wygnania z życia społecznego - i to zarówno dzieci oraz rodzin lekarzy, jak i ich samych - jest znakiem dezintegracji społecznej, ogólnego braku zaufania. Przy tym w społeczeństwach, w których ta dezintegracja jest posunięta dalej i w których rządy chylą się w stronę populizmu, zaufanie pozostaje ogólnie mniejsze, a więcej ludzi staje się antyszczepionkow$\mathrm{cami}^{\mathrm{i}}$.

Z jednej strony więc lekarze bywali społecznymi wygnańcami, których wspólnota wypychała na zewnątrz, z drugiej - mogli się stawać więźniami wraz ze swoimi pacjentami przebywającymi za śluzami oddziałów zakaźnych. Taki przypadek spotkał medyków z kaliskiego szpitala:
》W związku z tym sanepid wydał kuriozalną moim zdaniem decyzję, żeby zamknąć oddział z pacjentami i całym personelem w środku. A wszystko po to, aby zabezpieczyć opiekę nad chorymi. Zakazano nam wychodzić pod groźbą grzywny. Mieliśmy przez i4 dni przeby- wać w oddziale na kwarantannie. Dyrekcja kazała nam w tym okresie normalnie zajmować się pacjentami. Klatkę schodową na naszym oddziale zabito deskami - odcięto w ten sposób naszą dyżurkę od reszty szpitala. Jedzenie zostawiano nam pod drzwiami. Poza telefo- nami, nie mieliśmy kontaktu ze światem ${ }^{\mathrm{I} 6}$.

Natomiast dawna pustelnia, która wiązała się z odosobnieniem anachoretów i wyrzeczeniem się przez eremitów życia we wspólnocie, dziś wydaje się raczej luksusem, ponieważ odizolowana przestrzeń kosztuje ${ }^{\mathrm{I} 7}$. Bogaci gracze globalne-

14 Zob. https://fakty.tvn24.pl/ogladaj-online,60/hejt-wobec-medykow-chorzy-ludzie-wyzywaja-i-groza-stad-kampania-spoleczna-wylecz-nienawisc,1080348.html (stan z 18 sierpnia 2021 r.), podobnie https:/www.rp.pl/sluzba-zdrowia/art236221-koronawirus-grozby-wobec-lekarzy-informujacych-w-mediach-o-epidemii ( $\operatorname{stan}$ z 10 marca 2021 r.).

15 P. Żuk, P. Żuk, Right-Wing Populism in Poland and Anti-Vaccine Myths on Youtube. Political and Cultural Threats to Public Health, „Global Public Health” 2020, t. 15, nr 6, s. 790-804.

16 Zob. https://www.medexpress.pl/lekarze-uwiezieni-w-pracy-klatke-schodowa-zabito-deskami/ 77570 (stan z 9 sierpnia 2021 r.).

17 Zob. https://www.dw.com/p1/dok\%C4\%85d-przed-wirusem-uciekaj\%C4\%85-bogaci-amerykanie/ 
go rynku z USA chętnie inwestują w schrony na bezpiecznych wyspach, jak w Nowej Zelandii - co jest nieco nowocześniejszą wersją izolacji elity opisanej w Dekameronie. Część prywatnych bunkrów szykowanych na apokalipsę znalazła zastosowanie właśnie jako antywirusowe pustelnie, ale służyły temu także prywatne jachty, na które uciekali chcący się odizolować zatroskani o zdrowie poszukiwacze azylu ${ }^{\mathrm{I} 8}$.

Poza pandemią ze zjawiskiem odcięcia się mamy do czynienia w przypadku bikikomori. To znany z Japonii fenomen dotyczący osób, które skrajnie izolują się od społeczeństwa - przestają wychodzić z własnych pokojów, nie uczestniczą w życiu społecznym. Hikikomori nie komunikują się z nikim oprócz członków rodziny, często jednak nie wpuszczając ich do pokoju; jedynie odbierają jedzenie zostawione pod drzwiami. Długotrwałe życie bez interakcji społecznych może przy tym prowadzić do zaburzeń psychicznych. Jeden $z$ takich bikikomori jest ukazany w koreańskim filmie Parasite - kiedy zamyka się w piwnicy i wycofuje z życia społecznego, ukrywając się przed nim, nie podejmując jego wyzwań, unikając porażki.

\section{RELACJE I WIEDZA}

W zakresie rozporządzania informacją, mogącego prowadzić do izolacji informacyjnej jednostek czy grup, mamy do czynienia z brakiem lub nadmiarem wiedzy. W kwestii uczestnictwa w relacji, której skrajnym przejawem jest izolacja społeczna, mamy zaś do czynienia z deficytem lub przerostem relacji. To daje nam cztery sytuacje, którym przyporządkujemy przykładową narrację filmową:

a) brak wiedzy - możemy mieć wówczas do czynienia $\mathrm{z}$ agresją, wpisaną w mechanizm kozła ofiarnego - z powodu lęku przed odmiennością (jak w opartym na powieści Goldinga filmie Wtadca Much Hooka, w którym chłopcy, niechcący się podporządkować, są usuwani z grupy);

b) nadmiar wiedzy - który doprowadza do odrzucenia społeczeństwa, transgresji, ucieczki do pustelni z powodu lęku przed zbiorowością (jak w historii Edipus Rex Passoliniego, kiedy Edyp, porażony prawdą, udaje się na wygnanie);

c) brak relacji - który jest samotnością i prowadzi do depresji, otępienia (jak 
w filmach Lobster Lanthimosa czy Her Jonze'a, gdzie brak relacji odczłowiecza, a jej komputerowa symulacja sprawia, że to życiu stawiamy pytanie o autentyzm);

d) nadmiar relacji - który jest niemożliwością odnalezienia prywatności, miejsca dla siebie, swego rodzaju zaszczuciem i prowadzi do regresji, ucieczki, choroby umysłowej, szaleństwa (jak w filmach Dom wariatów Koterskiego czy Lśnienie Kubricka).

Żeby odzyskać samokontrolę, człowiek w warunkach izolacji usiłuje opowiedzieć o sobie inną historię. To odzyskanie kontroli odbywa się przez reinterpretację, zmianę ram sytuacji, w której ktoś chce się odnaleźć. Na naszej mapie izolacji mielibyśmy zatem do czynienia $\mathrm{z}$ ruchem, który następuje $\mathrm{z}$ jednego pola - sposobu rozumienia swojego położenia - ku drugiemu polu. A więc więzień może zamienić się w pustelnika: uciekając od systemu, zaczyna wewnętrzną emigrację. Obrońcy z oblężonej twierdzy mogą natomiast okazać się skazanymi na zagładę przez większą część społeczeństwa. Wówczas ich bohaterska obrona zostaje sprowadzona do bycia jedynie mięsem armatnim, staje się ich więzieniem. Taką sytuację można odnieść do obrony Stalingradu, nieudanej akcji ratunkowej na statku rosyjskim Kursk albo do położenia lekarzy uwięzionych w kaliskim szpitalu.

\section{REINTERPRETACJE, CZYLI ZMIANA STATUSU}

Różne rodzaje przesunięć, czyli ruchu w tym kontekście (wiedza - relacje) tworzą klasyczne sytuacje dramatyczne - za przykład niech posłuży historia Edypa, w której bohater jako dziecko został wygnańcem, następnie, by uniknąć fatum, udał się dobrowolnie na tułaczkę i został królem (Król Edyp), jako władca Teb oślepił się i odizolował od społeczeństwa, by skończyć w randze świętego pustelnika, który niesie pomyślność Atenom (Edyp w Kolonos). Przy tym warto zauważyć, że inspiracją do napisania sztuki przez Sofoklesa mogła być zaraza w Atenach u progu wojny peloponeskiej, kiedy zasadniczo szukano kozła ofiarnego, którego wygnanie czy zniszczenie mogło „oczyścić atmosferę”. Inne role i naprzemienne włączanie się do społeczeństwa oraz izolowanie się od niego wynikają właśnie z nowej wiedzy, która wpływała na odnajdywanie siebie w relacjach.

Ale ruch ten nie musi być oczywisty. Czasami narracyjny zwrot redefiniuje sytuację, w której człowiek czuje się więźniem czy wygnańcem. Wówczas mamy do czynienia z zaprzeczeniem konwencji wolności.

W takich okolicznościach redefinicji ram był na przykład Kaspar Hauser, który uwolniony, a więc mogący zaspokoić swój deficyt relacji i informacji, odczuwa ich nadmiar i postrzega się jako więzień tego świata. Druga postać graniczna to Don 
Kichot: nie ma on kontaktu z rzeczywistością, w której atakuje wiatraki, zatem buduje w swoim umyśle twierdzę, gdzie toczy walkę z bestiami.

\Wspominając pierwsze tygodnie pobytu w Norymberdze, Hauser jak twierdził - czuł ból w całym ciele. Za żadne skarby świata nie chciałby powtórnie przeżyć tego okresu - dałby się raczej zabić. Łatwo więc pojąć, że biedak niczego nie pragnął tak gorąco, jak tego, by co rychlej opuścić świat, w który został rzucony, i wrócić do swego dawnego stanu, choć ponurego i samotniczego, lecz przecież spokojnego i wolnego od cierpień. Jeszcze dwa tygodnie przed przyjściem do mnie, jak sam opowiadał - tęsknił za swoją klatką. [...] Wydawało mu się, że nigdy nie będzie mu dobrze, jeśli nie wrócić do klatki ${ }^{\mathrm{I}}$.

Motyw dziecka natury, wychowywanego w lesie w izolacji od ludzi przez niedźwiedzie lub wilki i trafiającego do cywilizacji miejskiej, był popularny w romantyzmie i ogólnie roussowskim ujęciu, w którym naturę utożsamiano z beztroską. Jak pisze Maria Janion:

\section{\Condillac w dziele O pochodzeniu wiedzy ludzkiej opowiadał o znale- zionym w i694 roku w lasach litewskich dziecku, które żyło wśród niedźwiedzi. Nie zdradzało ono żadnych oznak rozumu, chodziło na nogach i rękach, nie umiało wcale mówić i wydawało dźwięki w ni- czym niepodobne do ludzkich. Rousseau dorzucił do tego repozyto- rium dziecko z Hesji znalezione w I344 roku, które - odłowione i umieszczone na dworze księcia Henryka, mówiło potem, że gdyby to od niego zależało, wróciłoby do wilków ${ }^{20}$.}

W ten ciąg dzieci-znajd wpisuje się Mowgli Kiplinga czy komiksowy Tarzan, będący jednak już bardziej medium między naturą i kulturą, jakimś rozwiązaniem dla ich konfliktu, który romantyzm rozstrzygał na rzecz natury, a oświecenie kultury. Tymczasem popatrzmy na te postaci od strony konsekwencji długotrwałej izolacji. Ich integracja ze społeczeństwem byłaby możliwa tylko przy udziale prawidłowej komunikacji. Bez podstaw wspólnoty, zwłaszcza wspólnoty komunikacyjnej w ustanowionym świecie, jednostka pozostałaby do końca wyobcowana.

19 G. Daumer, Kaspar Hauser i jego jestestwo, jego niewinnośc, jego cierpienia i jego pochodzenie, w: Galernicy wrażliwości, red. M. Janion, S. Rosiek, Gdańsk 1981, s. 133-134.

20 M. Janion, „Larvatus Prodeo...”, w: Galernicy wrażliwości, s. 154. 


\section{IZOLACJA I STATUS PRAWDY}

Jeśli mielibyśmy patrzeć na te cztery pola pod kątem stosunku do prawdy, to jawi nam się taka macierz: Pustelnik izolujący się od społeczności odkrywa prawdę przez iluminację. Obrońca twierdzy izolujący innych od swej społeczności broni prawdy, która jest zewsząd atakowana - wprost lub przez spiski. Tułacz, izolowany od społeczności, nie mając żadnego punktu odniesienia, będzie musiał uznawać zmienność i względność prawdy. Natomiast więzień, izolowany przez społeczność, pozbawiony źródeł prawdy, będzie skazany na domniemanie prawdy, przypuszczenia, tymczasowe założenia.

Kim był zatem Kaspar Hauser? Był paradoksalnie - jako uwolniony z piwnicy niezintegrowanym członkiem społeczności, właśnie tułaczem, pozbawionym punktów zaczepienia wspólnoty, w ramach których można by podzielać wiedzę o świecie społecznym. Pierwszy przypadek - Hausera - to wyobcowanie w społeczności.

Drugi przypadek dotyczy zaś również wyobcowania wewnątrz społeczności gdy w wyniku przemocy zostaje zerwana relacja. Przemoc bowiem - pisze James Gilligan - to jeden ze sposobów izolacji społecznej:

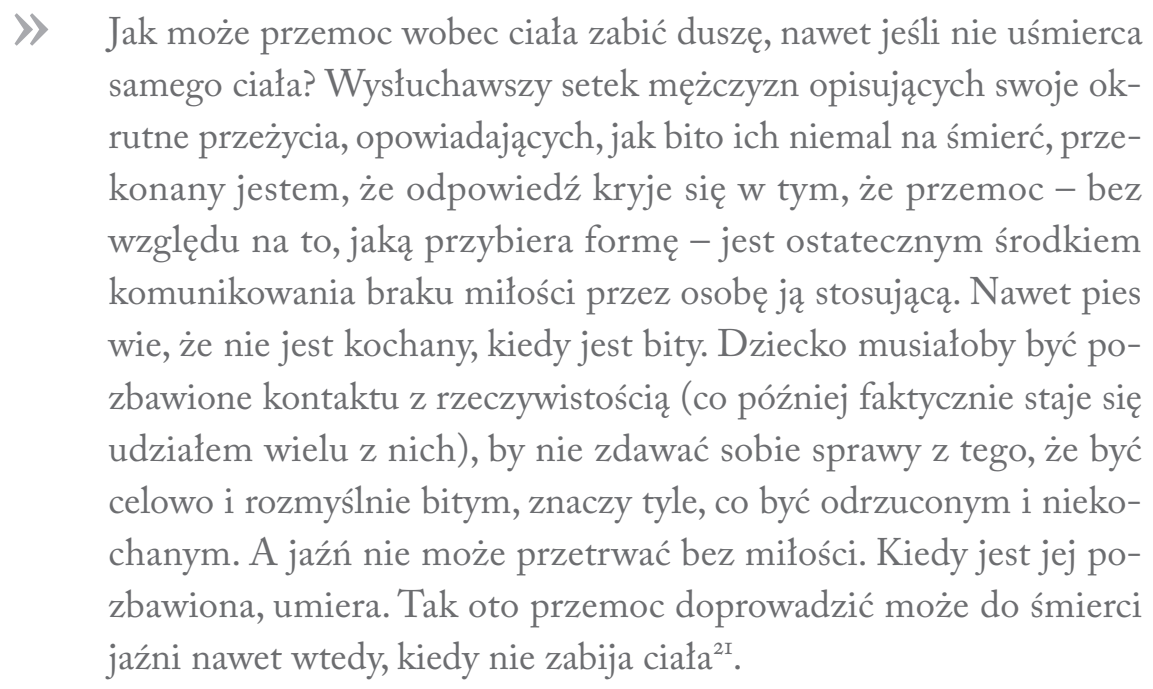

A zatem przemoc (przynajmniej długotrwała) wobec dziecka jest wygnaniem go ze społeczności, z relacji. Opuszczone i niezintegrowane ponownie przez brak społecznej akceptacji, na zawsze już pozostaje wygnańcem, poruszając się bez relacji po pustkowiu pełnym ludzi. 
Trzeci przypadek to więzienie wewnętrzne, w którym jesteśmy skazani na domniemania o świecie zewnętrznym, gdyż bodźce pochodzące stamtąd nie integrują się w sensowne całości. Można tu odnieść się do kategorii „odosobnienia” zaproponowanej przez Domerackiego, czyli depersonalizacji, dekompozycji lub destrukcji bycia osobowego (jako osoby) ${ }^{22}$. W kontekście komunikacji taki przypadek opisuje Aleksandr Euria w książce Świat utracony i odzyskany ${ }^{23}$. Jego pacjentowi kula przebiła czaszkę i uszkodziła mózg. Przy tym rozbiła obraz świata na tysiące części, których później nie mógł złożyć w całość. Pozbawiła go przeszłości. $\mathrm{Z}$ wysiłkiem przypominał sobie słowa, składał oddzielne zdania, starał się uchwycić sensy:

\Znajduję się jakby w we mgle, w ciężkim półśnie, w pamięci pustka, nie mogę sobie przypomnieć ani jednego słowa, tylko przemykają mi obrazy, niewyraźne przywidzenia, które szybko pojawiają się i szybko znikają; ani jednego obrazu nie jestem w stanie zrozumieć ani zapamiętać ${ }^{24}$.

Zasiecki, pacjent Łurii, był w stanie daleko posuniętej izolacji informacyjnej nie tyle ze świata, ile z własnych zmysłów. Nie mógł ze swoich spostrzeżeń nic odczytać, złożyć fragmentów w sens. Był wolny, ale stał się więźniem własnych sił poznawczych, które nie pozwalały mu wyjść poza swoje wnętrze, zostawiając jedynie niewielkie okienko do kontaktu ze światem. Za każdym razem musiał domniemywać, zgadywać, przypuszczać, czym jest to, czego właśnie doświadcza. Niczym Don Kichot, nigdy nie był pewny, czy kształt przed nim jest smokiem czy wiatrakiem.

\section{Podsumowanie}

Najważniejsza dla poczucia izolacji jest kontrola wtórna. Kontrola pierwotna pozwala nam sterować swoim działaniem, przystosowywać świat do własnych potrzeb. Kontrola wtórna, kiedy nie bardzo mamy wpływ na to, co się dzieje, pozwala nam natomiast sterować oczekiwaniami lub nadawać faktom taki sens, by móc je zaakceptować. Położenie pustelnika i tułacza różni się więc postawą wobec izolacji, podobnie los obrońcy twierdzy i więźnia. Tę sytuację definiują narracje o własnej tożsamości, które jednostka po pierwsze może komunikować grupie, po drugie

22 P. Domeracki, Rozstaje samotności..., s. 50.

23 A. Łuria, Świat utracony i odzyskany, tłum. A. Kowaliszyn, Warszawa 1984.

24 Ibidem, s. 19. 
jednostki mogą je rozpowszechniać względem siebie we wspólnocie, po trzecie grupa komunikuje je wobec jednostki, więżąc ją lub wypychając ze społeczeństwa. Poczucie izolacji może wynikać z dystansu fizycznego, jakim jest na przykład oddzielenie na wyspie, lub z dystansu komunikacyjnego, jakim jest z kolei niemożność stworzenia relacji (Kaspar Hauser) czy odczytania sensu docierających informacji (pacjent Łurii). Chodzi wszakże o to, byśmy w naszych symbolicznych światach nie pozostawali samotni albo w zbyt dużej sprzeczności z innymi.

Pozytywne lub negatywne wartościowanie izolacji dotyczy więc możliwości wymiany ze światem. Zakręcamy kurek $\mathrm{z}$ komunikacją, gdy wydaje nam się ona zatruta, i odkręcamy, kiedy możemy zaspokoić pragnienie wspólnoty.

Społeczeństwo jest zatem siecią komunikacyjną, która stwarza relacje. Z zasady okazuje się ono „informacyjne” - ale duża część informacji to definicja tego, co i jak łączy ludzi, niezależnie od technologii.

\section{Bibliografia}

Augé M., Nie-miejsca. Wprowadzenie do antropologii hipernowoczesności, tłum. R. Chymkowski, Warszawa 2011.

Bauman Z., Globalizacja, tłum. E. Klekot, Warszawa 2000.

Baumeister R., Zwierzę kulturowe, tłum. D. Stefańska-Szewczuk, Warszawa 2011.

Berger P., Luckmann T., Spoteczne tworzenie rzeczywistości, tłum. J. Niżnik, Warszawa 1983.

Bohusz F.K., Dziennik podróży, wstęp i oprac. F. Wolański, Kraków-Wrocław 2014.

Daumer G., Kaspar Hauser i jego jestestwo, jego niewinność, jego cierpienia i jego pochodzenie, w: Galernicy wrażliwości, red. M. Janion, S. Rosiek, Gdańsk 1981.

Dijk T. van, Działanie, opis dziatania a narracja, tłum. M.B. Fedewicz, w: Narratologia, red. M. Głowiński, Gdańsk 2004.

Domeracki P., Rozstaje samotności. Studium filozoficzne, Kraków 2016.

Gilligan J., Wstyd i przemoc. Refleksje nad śmiertelna epidemia, tłum. A. Jankowski, Poznań 2001.

Habermas J., Faktizität und Geltung, Frankfurt am Main 1998.

Janion M., „Larvatus Prodeo... ”, w: Galernicy wrażliwości, red. M. Janion, S. Rosiek, Gdańsk 1981.

Kapuściński G., Tańce wokót krzyża. Analiza semiostrukturalna zachowañ podczas demonstracji pod Patacem Prezydenckim, „Miscellanea Anthropologica et Sociologica” 2012, nr 13.

Laclau E., Rozum populistyczny, tłum. T. Szkudlarek et al., Wrocław 2009.

Euria A., Swiat utracony i odzyskany, tłum. A. Kowaliszyn, Warszawa 1984.

Narracja jako sposób rozumienia świata, red. J. Trzebiński, Gdańsk 2002.

Niedźwieńska A., Poznawcze mechanizmy znieksztatceń w pamięci zdarzeń, Kraków 2004.

Oleś P., Autonarracyjna aktywność cztowieka, w: Narracja. Teoria i praktyka, red. B. Janusz, K. Gdowska, B. de Barbaro, Kraków 2008.

Pariser E., The Filter Bubble. How the New Personalized Web Is Changing What We Read and How We Think, New York 2012.

Scott W., The Life Of Napoleon Buonaparte, Emperor Of The French, J\&B Williams, Cambridge1832. 
Topolski J., Jak się pisze i rozumie historię, Poznań 2008.

Valentine V., The 'Notness' Principle - a Semiotic Model of Meanings, dokument prezentowany na Market Research Society Training Seminar, Londyn, luty 2001.

Zahorski T., Zendran I., Ztoty wiek grypy. Krótka historia pandemii, w: Acta Uroboroi. W kręgu epidemii, red. M. Dąsal, Wrocław 2018.

Zrozumieć samotność. Studium interdyscyplinarne, red. P. Domeracki, W. Tyburski, Toruń 2006.

SŁOWA KLUCZE: media, semiotyka izolacji, deficyt informacji, teorie spiskowe

\section{ISOLATION AND COMMUNICATION. TYPES OF ISOLATION AND CONNECTED WITH THEM COMMUNICATION DEFICITS}

The article considers various types of isolation and the communication deficits that characterize them. Taking into account oppositions: individual-collective and willcoercion, the following four isolation situations could be created: when a group isolates itself from others (stronghold), when a group isolates individuals from itself (prison), when an individual isolates itself from others (hermitage) and when an individual is not able to integrate with others (wilderness). These four situations have consequences in how a person communicates, gaining control over the environment, and how he deals with problems through the interpretation of events.

These situations are also associated with a specific body of knowledge and the ability to dispose of it, and the ability to regulate relationships with others. As examples of the intersection of these categories - knowledge and relations - the article cites the fate of doctors in a pandemic and conspiracy theories related to it, as well as key cases of certain problems in communication, such as the case of Kaspar Hauser or Japanese bikikomori.

KEY wORDs: media, semiotics isolation, information deficit, conspiracy theories 